Article

\title{
BIM-Based Incremental Cost Analysis Method of Prefabricated Buildings in China
}

\author{
Yuan Qi, Siwei Chang *, Yingbo Ji and Kai Qi \\ School of Civil Engineering, North China University of Technology, Beijing 100043, China; \\ hu_xb1@sina.com (Y.Q.); yingboji@126.com (Y.J.); sangshiqikai@163.com (K.Q.) \\ * Correspondence: SiWei_Chang@126.com; Tel.: +86-135-8165-1934
}

Received: 23 September 2018; Accepted: 12 November 2018; Published: 20 November 2018

\begin{abstract}
In order to achieve the sustainable growth of its urbanization and natural resources, China has been making great efforts to develop prefabricated construction technologies. However, the high incremental cost of prefabricated buildings (PRBs) is a fundamental obstacle to the latter. The current study mainly focuses on analyzing the incremental cost of the on-site construction stage. It is hard to comprehensively identify the incremental cost composition without considering the incremental cost caused by prefabricated components (PFCs) production. Moreover, the results of incremental cost calculation are not accurate enough by comparing the cost of two similar but different PRB and traditional buildings (TRB), and the case-based calculation results suffer from a lack of representation. To address these issues, we first establish a two-dimensional incremental cost index system from the dimension of cost items and prefabricated technologies to study the incremental cost composition of the whole construction stage. Additionally, based on China's latest policies documents, the applicability of incremental cost composition items can also be improved. Then a building information modeling (BIM)-based calculation model is presented to avoid the calculation error caused by comparing the cost of two different PRBs and TRBs. To validate the proposed index system and calculation method, an actual prefabricated project in China is also conducted as a case study. The results suggest that: (1) Incremental cost is composed of band bearing and retaining walls and inner walls PFCs production, PFCs hoisting and grouting, post-pouring concrete, and full decoration. (2) The BIM-based incremental calculation result of a PRB case from Shanghai is within the range of the national average PRB incremental estimation results. The incremental cost composition items and BIM-based calculation approach can greatly help investors to identify the largest increase in cost and make effective cost optimization strategies.
\end{abstract}

Keywords: prefabricated building; incremental cost; policy documents; BIM

\section{Introduction}

In recent years, the development of population urbanization in China has been booming. This speeding process of urbanization is undoubtedly associated with higher demand for the improvement of housing conditions and the living environment. By 2020, China's population is expected to reach up to 1.42 billion, and the urbanization rate will increase tremendously from $58.47 \%$ to $60.02 \%$, as predicted by the National Health Commission of the People's Republic of China [1,2]. The current construction industry in China cannot meet the fast growing demand for urban housing. Furthermore, the area of completed buildings has continued to decline in recent years, with a year-on-year decline of $11.2 \%$ from January to August, 2018 [3]. At the same time, extensive construction methods have also brought material waste such as steel bar, concrete, timber formwork, and resources waste such as water and electricity [4]. Therefore, in order to realize the sustainable development of urbanization and natural resources in China, there is an urgent need for the construction industry to be reformed 
with more innovative technologies. Prefabricated construction technology has been introduced and implemented to mitigate these challenges [5,6].

Prefabricated technology is defined as a semi-manufacturing construction method, in which every building component can be freely selected to achieve automated production in factories, and is assembled on site. Due to its unique advantages such as fast construction progress, high quality, and reduced waste of resources, this innovative technology has been highly noticed by the Chinese government and related enterprises. The Ministry of Housing and Urban-Rural Development of the People's Republic of China clearly stated in 2017 that China will strive to increase the proportion of prefabricated building (PRBs) to $30 \%$ of the new building area, and increase the number of highly skilled industrial workers to 3 million within 10 years [7]. A great number of leading Chinese real estate enterprises such as Vanke, Country Garden, and China Grand Enterprises have also successively established PRBs and carried out their large-scale construction [8].

Prefabricated technology has been extensively used around China in recent years, however, the implementation of PRBs in various regions of China face the barrier of cost increase [9]. In response to this, the Chinese government has issued incentive policies to deal with incremental cost, such as Beijing's "Implementation Opinions on Accelerating the Development of Prefabricated Buildings" (People's Government General Office, 2018). This document refers to the financial incentives available to firms which prioritize increment cost. These incentives are given to those who opt to construct PRBs and meet implementation standards. However, due to a lack of experience, the industry has not yet figured out in a detailed way the composition of incremental cost index (the incremental cost items relating to the use of assembly construction technology) and quantitative calculation method. Without accurate analysis of incremental cost, it will be difficult for contractors to make profit even if they accept incentive policies and it is also hard for the government to develop and update reasonable standards and regulations for the distribution of subsidies.

\section{Brief Literature Review}

Many studies have proposed factors that lead to a substantial increase in costs $[10,11]$, such as the technical system not being standardized, the management mode not being uniform, etc. [12]. In order to eliminate those factors, and to accelerate the spread of PRBs, a number of studies have made proposals based on experiences and qualitative analysis method, involving: (1) the intensification of policy support such as financial supports and tax reform; (2) a focus on technological innovation and personnel training; (3) the recruitment of industrial workers to exploit the advantages of reduced labor costs; and (4) the promotion of integrated design, production, and construction, and the strengthening of cooperation between various entities in the industry chain [13,14]. However, although many studies have proposed feasible improvement measures and recommendations, the incremental cost of PRB has not declined $[15,16]$.

To clarify exactly where incremental costs come from, Li et al. [17] used expert interviews and a questionnaire-based survey to study the impact of changes in the value chain on the costs of prefabricated components (PFCs). The results indicated that the market structure of each link in the value chain consists of land costs, pre-development costs, PFC production costs, PFC transportation costs, PFC on-site assembly costs, and running costs. Additionally, Wang et al. [18], conducting statistical analysis, calculated the incremental costs of civil, decorative, and installation projects based on a PRB projects of Shanghai. These studies concluded that the incremental cost of civil projects was the highest [19]. There are many current studies which focus on the calculation method for incremental costs of civil projects at the on-site assembly stage. The methods of comparative analysis and case studies are mainly used for the quantitative calculation of incremental costs. Xiao et al. [20] concluded that the PRB incremental cost is $32 \mathrm{yuan} / \mathrm{m}^{2}$; they obtained this result by comparing the civil project budget costs of a residential building designed in accordance with the PRB design scheme and traditional design scheme based on bid documents and construction drawing. Furthermore, Wang et al. [21] calculated that the range of PRB incremental cost is between 200 and $500 \mathrm{yuan} / \mathrm{m}^{2}$. 
This conclusion was based on real civil projects costs of 12 pairs of existing PRB and traditional building (TRB) projects with the same structural form, similar building height, and similar construction times. Mao et al. [22] applied the multiple-case study method to conduct an in-depth analysis of the different expenditures involved in using PRB compared to conventional construction methods. Moreover, many numerical models have been deployed to calculate the PRB incremental cost of civil projects. Additionally, Lu et al. [23] proposed an incremental cost data model to predict the incremental costs of civil projects of other PRBs. Their results indicated that PRBs cost 461.41 yuan $/ \mathrm{m}^{2}$ more than TRBs. However, due to the immaturity of PRB development in China, there is a lack of adequate data and case records. This means that many studies must use qualitative analysis methods (i.e., expert interviews) to investigate the incremental costs of PFC production [24].

Given the rapid development of the PRB industry, it is a challenge for researchers to keep pace. The research gaps are caused by insufficient cost data. The PRB cases to be studied are summarized as follows:

- Variables such as building structure and component's positions have a great impact on the accuracy of incremental cost calculation, and there will be a large difference in these variables in two different buildings, so it is hard to guarantee the accuracy of the incremental cost comparison results of two similar but different PFB and TRB. Additionally, there is a large difference (i.e., PFC types, construction location, etc.) in study cases, and the incremental analysis results cannot present the overall situation of the prefabricated industry.

- There is no suitable method to obtain accurate and reliable cost data of the PFC production stage. Therefore, it is hard to quantitatively analyze the whole construction stage incremental cost (including the PFC production and on-site assembly stages).

Building information modeling (BIM) is an engineering data model that integrates various data from engineering projects based on three-dimensional (3D) digital technology [25]. The refined 3D model can be used to correlate the schedule and cost information of the whole construction process by simulation $[26,27]$. Additionally, the error rate for the cost calculation results can be effectively reduced through automatic calculations, utilizing BIM cost calculation software. In regards to BIM-based construction simulations, Joosung Lee et al. [28]. developed a new BIM-based 4D simulation framework to explore the improved management method for modular construction projects. Based on this new framework, a visually optimal manufacturing process from the three perspectives of resources, material, and quality can be identified and it was also verified that the proposed $4 \mathrm{D}$ framework reduces the time and cost needed for module manufacturing. Gulsum Sevde Baltasi et al. [29] demonstrated a pre-construction cost analysis method using BIM and prototype resource integrated planning and simulation software called GSimX, and proved that a BIM-based cost estimation method can help contractors evaluate time and cost results more quickly, more easily and with higher-quality. J L. [30] developed an integrated model that interrelates BIM with construction cost estimation, estimation, scheduling and sustainability at the conceptual design stage of the project to quickly make a reliable construction cost estimate, construction schedule, and preliminary sustainability evaluation for owners and designers.

The objective of this paper is to propose a two-dimensional incremental cost index system. This system is based on the elements of cost items and assembly technologies. The latest authority industry policy documents are used to effectively improve incremental cost composition adaptively and comprehensively in order to avoid the impact associated with the case-studies method on the applicability of the calculation results. Another objective is to propose a BIM-based incremental cost calculation model, in order to rationally transform the same PRB into TRB, which can make it more easy to calculate the incremental stage cost data of the PFC production stage and guarantee the high accuracy of the incremental cost calculation result. The last objective is to validate the accuracy of incremental cost composition items and the calculation approach through a case study from Shanghai. 


\section{Research Approach}

The first objective of this research is to identify the composition of the incremental cost of PRBs. In order to find out the detailed incremental cost index and improve the applicability of the a incremental cost index for all projects in the current PRB industry, this paper used a combination method of fishbone analysis [31] and semi-structured interview methods to propose a two-dimensional incremental cost index system from two dimensions of cost items and assembly technologies. Specifically, the system horizontally identifies each cost item based on the "PRB project consumption quota (TY01-01(01)-2016)" (CQ), while vertically analyzing the incremental cost of each assembly technology used, based on the "PRB Evaluation Criterion (GB/T51129-2017)" (EC). The kinds of cost items and assembly technologies showed in CQ and EC are based on the statistical information of all existing PRB projects around China. The fact that incremental cost analysis results can be better applied to different PRBs is the key reason for introducing CQ and EC.

The second objective was to develop a quantitative incremental cost calculation method of the total construction stage. To avoid the research gap of insufficient cost data of the PFC production stage and the incorrect cost data of manual calculation, 3D BIM model and cost simulation for the entire construction process (from production of prefabricated parts to main decoration) were applied.

As the cost difference between PRBs and TRBs mainly emerge at the construction stage [32], this paper targets the incremental costs of the construction process. Thus, in order to simplify the complicated study process, a research framework was established, as shown in Figure 1.

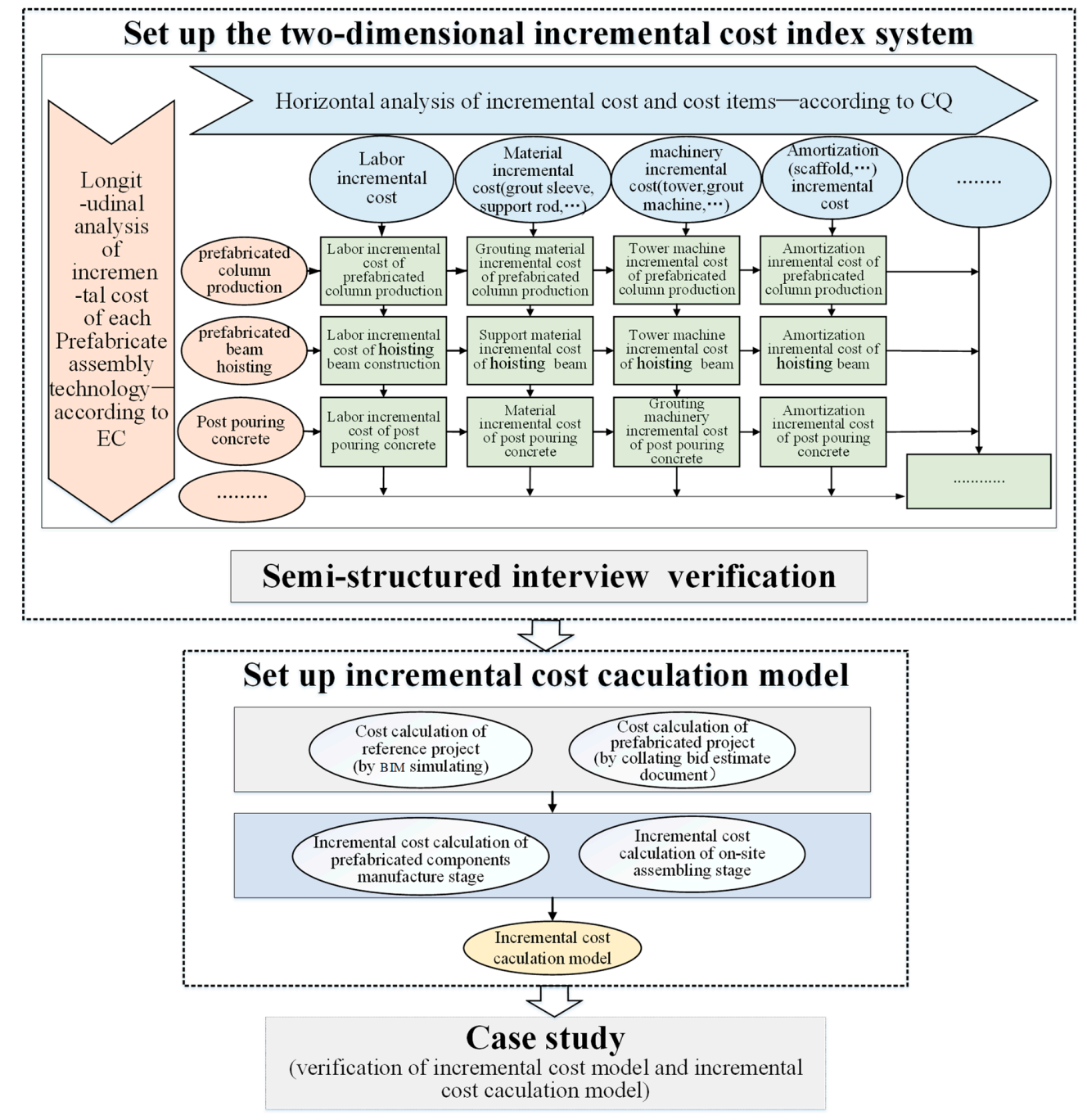

Figure 1. Research framework of PRB incremental cost. 


\subsection{Two-Dimensional Incremental Cost Index System}

The concept of incremental cost is developed from the concept of marginal cost [33]; it refers to the cost incurred due to the implementation of a specific plan. If a plan is not adopted, there will be no incremental cost. This is the definition method of the incremental cost method for green building, which is relatively mature [34-37]. This study defines the incremental cost of PRBs as the increased costs (the decreased costs are also recorded as incremental cost, with the symbol marked as negative) due to the selection of the assembly technology, according to the requirements of the CQ and EC. It includes direct incremental cost items (labor, materials, and machinery), and measures incremental cost items (template amortization, etc.), indirect incremental cost items (fees, overheads), tax and profit.

\subsubsection{Identification of PRBs Incremental Cost Items}

As there are fundamental differences between the structural forms and construction technologies of PRBs and TRBs, there will be large differences in the composition of cost items when they are transformed, using the traditional construction method, into assembly technology [38]. QC was prepared by Ministry of Housing and Urban- Rural Development of the People's Republic of China (MOHURD). It is based on the cost data statistical analysis results of every PRBs case across China and has been in use since March 2017. QC is an authoritative PRB calculation standard incorporating all kinds of PRB construction cost items related to unique PRB features and new assembly technologies (i.e., factory automatic manufacture, hoisting and grouting of PFCs and integrated decoration). In order to comprehensively identify incremental cost items, this study uses the fishbone analysis method to distinguish different cost items compared with the TRBs, according to QC. A fishbone analysis diagram of incremental cost items of PRBs was compiled from the four aspects of direct costs, indirect costs, measure costs, and profit and tax in Figure 2. In the figure, the cost items in italic subscript result from the adoption of assembly technology.

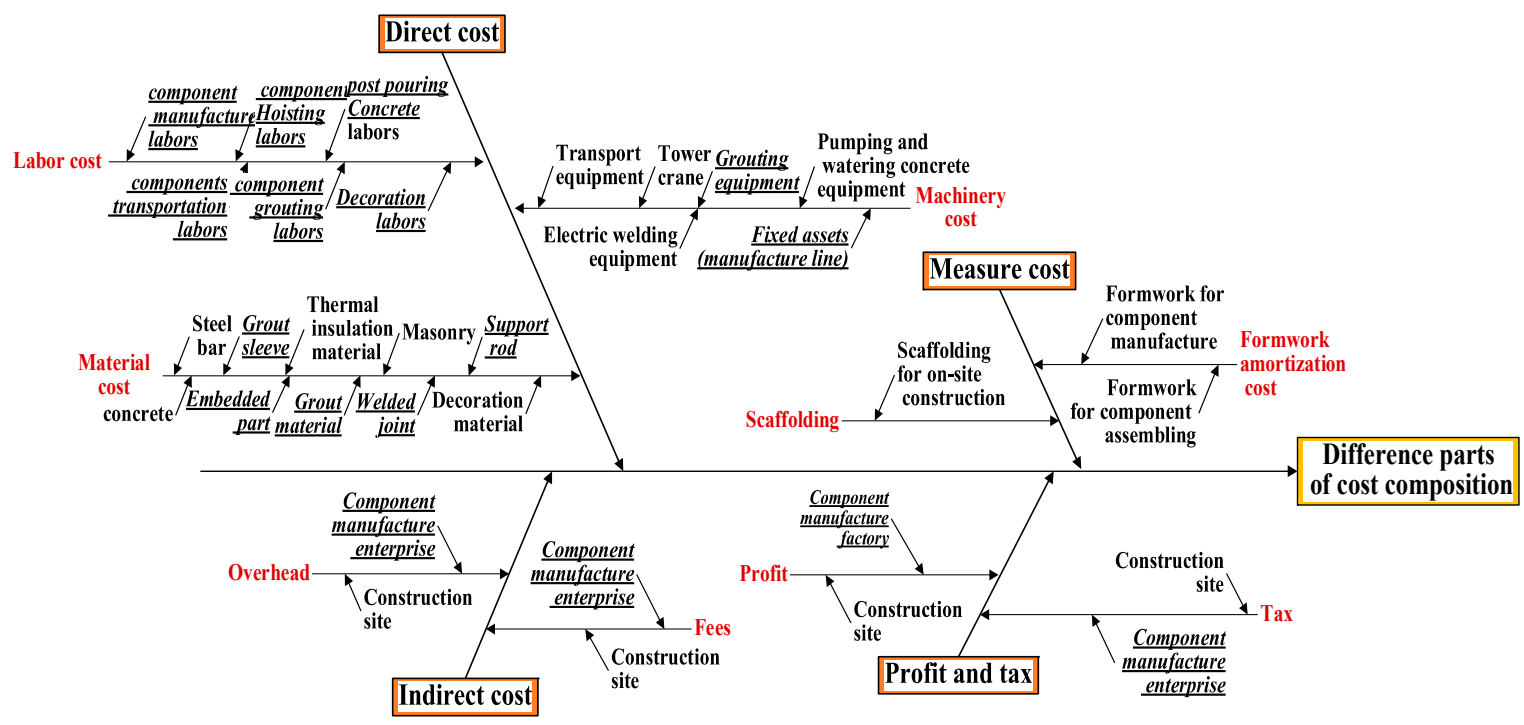

Figure 2. Fish bone analysis diagram of PRBs incremental cost items.

\subsubsection{Classification of PRBs Incremental Cost Items}

EQ is the only existing PRBs evaluation criterion. Prepared by MOHURD and in use since February, 2018, it is applicable to all PRBs in China. EQ was introduced to evaluate the degree of prefabrication of PRBs (the comprehensive ratio of prefabricated parts used in the main structure, the retaining wall, the inner partition wall, the decoration and the equipment pipeline above the outdoor floor [39]). The evaluation criteria are based on two aspects of PFC types and assembly technologies. All PRBs must be designed to meet the requirements of EQ. Evaluation scores are the 
basis for applications to receive policy subsidies. To render the calculation of the incremental cost of assembly technologies more scientifically, this study uses the cross classification method [40] to analyze incremental cost distributions for each assembly technology in the EQ (all incremental cost items are presented in Figure 2); these are then separated from the construction time dimension of PFCs production and on-site assembly construction stages, such as the material incremental cost of producing PFCs, which consist of concrete, rebar and grouting sleeves. In order to analyze the incremental cost for the whole PRB construction in greater depth and to make the method easier to use, this paper takes the EQ assembly technologies as its first-level index, and the incremental cost items of the PFCs production and on-site assembly construction stages as its secondary index. This was performed to generate the two-dimensional incremental index system, as shown in Table 1.

Table 1. Assembly technology incremental cost, and preliminary construction of two-dimensional index system.

\begin{tabular}{|c|c|c|c|}
\hline \multirow{2}{*}{\multicolumn{2}{|c|}{$\begin{array}{l}\text { Assembly Technologies } \\
\text { (First-Level Indicators) }\end{array}$}} & \multicolumn{2}{|c|}{ Incremental Cost Distribution and Classification } \\
\hline & & $\begin{array}{l}\text { PFCs Production Stage } \\
\text { (Second-Level Indicators) }\end{array}$ & $\begin{array}{c}\text { On-Site Assembly Construction Stage } \\
\text { (Second-Level Indicators) }\end{array}$ \\
\hline \multirow{2}{*}{$\begin{array}{l}\text { Load-bearing structural } \\
\text { components construction } \\
\text { (automatically factory } \\
\text { product, }\end{array}$} & $\begin{array}{l}\text { Columns, load-bearing } \\
\text { walls, ductile wall panels, } \\
\text { etc. vertical load-bearing } \\
\text { components }\end{array}$ & \multirow{2}{*}{$\begin{array}{l}\text { Labor cost: labor cost for structural components production } \\
\text { Material cost: rebar, concrete, grout sleeves, insulation parts } \\
\text { for bearing structural components production } \\
\text { Machinery cost: fixed asset, manufacture line } \\
\text { Measure cost: formwork amortization } \\
\text { Other costs: overheads, taxes, transportation fee }\end{array}$} & \multirow{2}{*}{$\begin{array}{l}\text { Labor cost: bearing structural components hoisting, grouting } \\
\text { and post-concrete pouring labor } \\
\text { Material cost: bearing structural components supporting rods, } \\
\text { grouting material, rebar, concrete } \\
\text { Machinery cost: grouting machinery, tower crane } \\
\text { Measure cost: formwork, scaffold } \\
\text { Other cost: overheads, taxes, profit }\end{array}$} \\
\hline & $\begin{array}{l}\text { Beams, slabs, stairs, } \\
\text { balconies, air } \\
\text { conditioning panels and } \\
\text { other cover members }\end{array}$ & & \\
\hline \multirow[t]{2}{*}{$\begin{array}{l}\text { Non-load-bearing } \\
\text { components }\end{array}$} & $\begin{array}{l}\text { Outer maintenance } \\
\text { components }\end{array}$ & \multirow{2}{*}{$\begin{array}{l}\text { Labor cost: Non-load-bearing components } \\
\text { construction labor } \\
\text { Material cost: rebar, concrete, grout sleeves, insulation parts } \\
\text { for non-load-bearing components construction } \\
\text { Machinery cost: fixed asset, manufacture line } \\
\text { Measure cost: formwork amortization; other costs: overheads, } \\
\text { taxes, transportation fees }\end{array}$} & \multirow{2}{*}{$\begin{array}{l}\text { Labor cost: Non-load-bearing components hoisting, grouting } \\
\text { and post-concrete pouring labor } \\
\text { Material cost: Non-load-bearing components supporting rods, } \\
\text { grouting material, rebar, concrete } \\
\text { Machinery cost: grouting machinery, tower crane } \\
\text { Measure cost: formwork, scaffold } \\
\text { Other cost: overheads, taxes, profit }\end{array}$} \\
\hline & Internal wall & & \\
\hline Decoration & Full decoration & - & $\begin{array}{l}\text { Labor, material, machinery costs for floor, } \\
\text { baseboard, wall roof and ceiling decoration }\end{array}$ \\
\hline
\end{tabular}

\subsubsection{Verification and Correction of Two-Dimensional Incremental Index System}

Although this two-dimensional incremental index system has been developed using scientific research methods and with reference to authoritative policy documents, since QC and EQ have only recently been implemented, it is a challenge to verify their accuracy in practice [41]. The expert interview method is a more reliable and convenient means to obtain reliable PRBs incremental cost information and is thus adopted here. This study used research experts in the field of industrial construction who spoke with personnel from leading PRB companies [42]. The latter were from the leading companies, including PFC manufacturing managers, PRB projects cost managers and EPC developers. This study included experts in the fields of engineering projects management, new industrial building, information construction technology, etc. The name, title and workplace information of each expert is shown in Table 2. In the interviews, researchers queried the accuracy of each incremental cost index item and the rationality of the index classification. Their objectives were to collect data on the actual conditions of nine prefabricated projects, utilizing their research experience, and to complete of the incremental cost index questionnaire. 
Table 2. The name, title, and workplace information of each experts.

\begin{tabular}{|c|c|c|}
\hline Letter ID & Title & Workplace \\
\hline A & Dean, School of Civil Engineering & North China University of Technology (Beijing, China) \\
\hline B & $\begin{array}{l}\text { Deputy Head of the School of Civil } \\
\text { Engineering }\end{array}$ & North China University of Technology \\
\hline $\mathrm{C}$ & $\begin{array}{l}\text { Assistant/professor of the construction } \\
\text { economic evaluation }\end{array}$ & North China University of Technology \\
\hline $\mathrm{D}$ & $\begin{array}{l}\text { Lecturer at the School of Smart } \\
\text { Construction }\end{array}$ & North China University of Technology \\
\hline $\mathrm{E}$ & Lecturer in project management & North China University of Technology \\
\hline $\mathrm{F}$ & Executive vice president (real estate) & Longxin Construction Group Co., Ltd. (Nantong, China) \\
\hline G & Professor-level senior engineer & Zhongjian City Construction Development Co., Ltd. (Beijing, China) \\
\hline $\mathrm{H}$ & $\begin{array}{l}\text { Director of Intelligent Director of the } \\
\text { Intelligent Manufacturing Department }\end{array}$ & Sanyi Group Co., Ltd. (Beijing, China) \\
\hline K & Senior engineer & Haimen City Construction Drawing Review Center (Haimen, China) \\
\hline $\mathrm{L}$ & Senior engineer & $\begin{array}{l}\text { Shanghai Zhongsen Building \& Engineering Design Consultant Co., } \\
\text { Ltd. (Shanghai, China) }\end{array}$ \\
\hline M & $\begin{array}{l}\text { Assistant/Professor of the project } \\
\text { evaluation }\end{array}$ & Tongji University (Shanghai, China) \\
\hline $\mathrm{N}$ & Chief Engineer & $\begin{array}{l}\text { Shenyang Wanrong Modern Construction Industry Co., Ltd. (Shenyang, } \\
\text { China) }\end{array}$ \\
\hline $\mathrm{O}$ & Lecturer of project economic management & Harbin Institute of Technology (Harbin, China) \\
\hline
\end{tabular}

Each incremental cost item in the index system has a higher frequency in actual projects, with more than $95 \%$ of incremental index items appearing seven times or more in nine actual prefabricated projects. The latter figures were obtained through the summary and analysis of interview results (the interview data analysis process is shown in Figure 3), thus further verifying the initial two-dimensional incremental cost index system. However, due to lack of practical experience, 15 experts advised that the material incremental cost items should be supplemented with embedded parts, thermal insulation, and masonry. Machinery increments needed to be supplemented with welding equipment and concrete vibrators.

In order to reduce the complexity of the index system and increase the availability of incremental cost data, the indicators hierarchy is divided and revised in accordance with the sequence of construction stages-assembly construction technology-incremental expense types, while five indicators of embedded parts were added on the basis of the original. The final two-dimensional incremental cost index system is shown in Figure 4. 


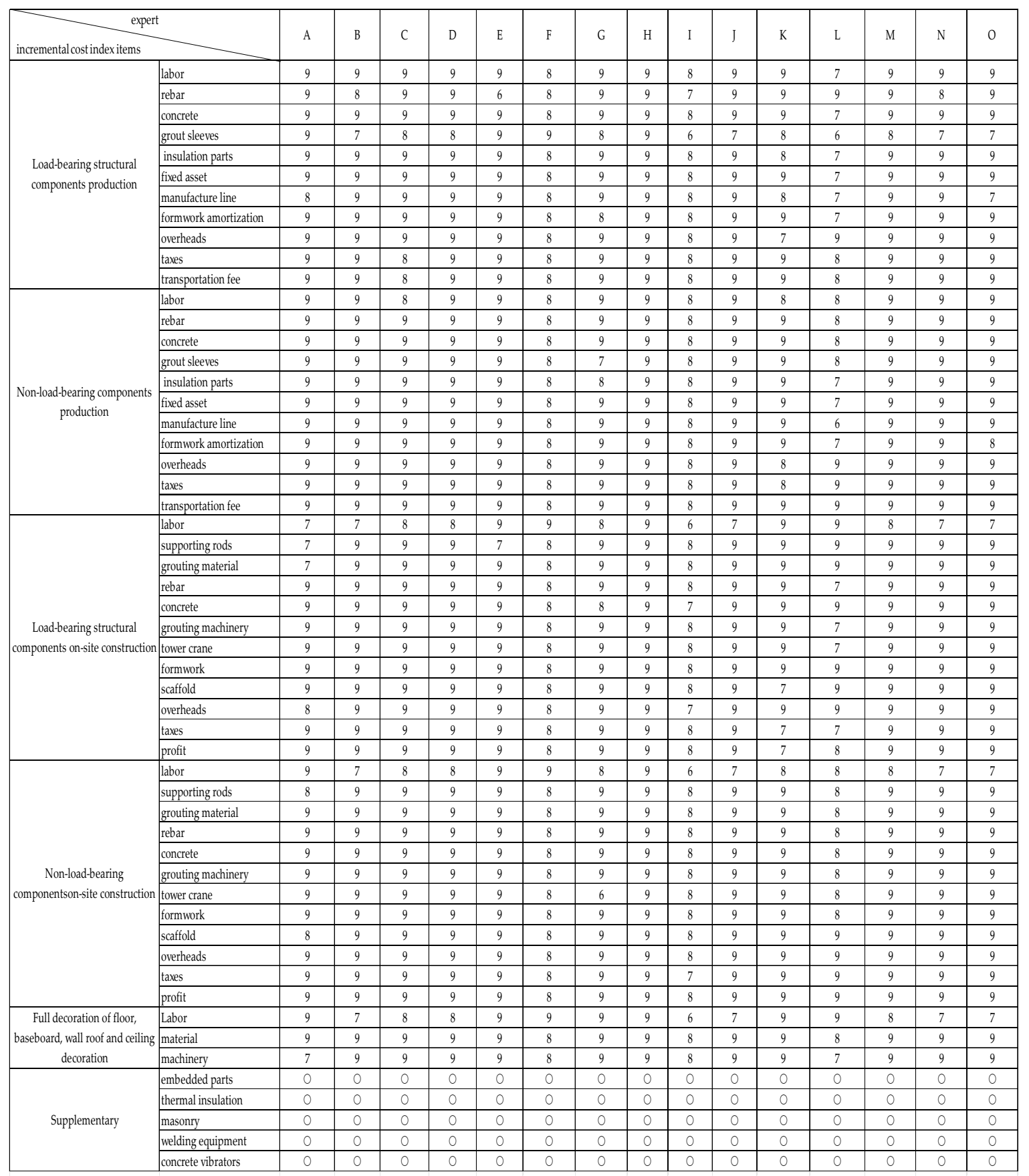

Figure 3. Interview data collation. A-O represent the experts mentioned in Table 2. The numbers shown in this figure represent the number of occurrences of each incremental cost index items in nine PRB projects. $\bigcirc$ represents the supplementary items which appear seven times or more in nine PRB projects. 


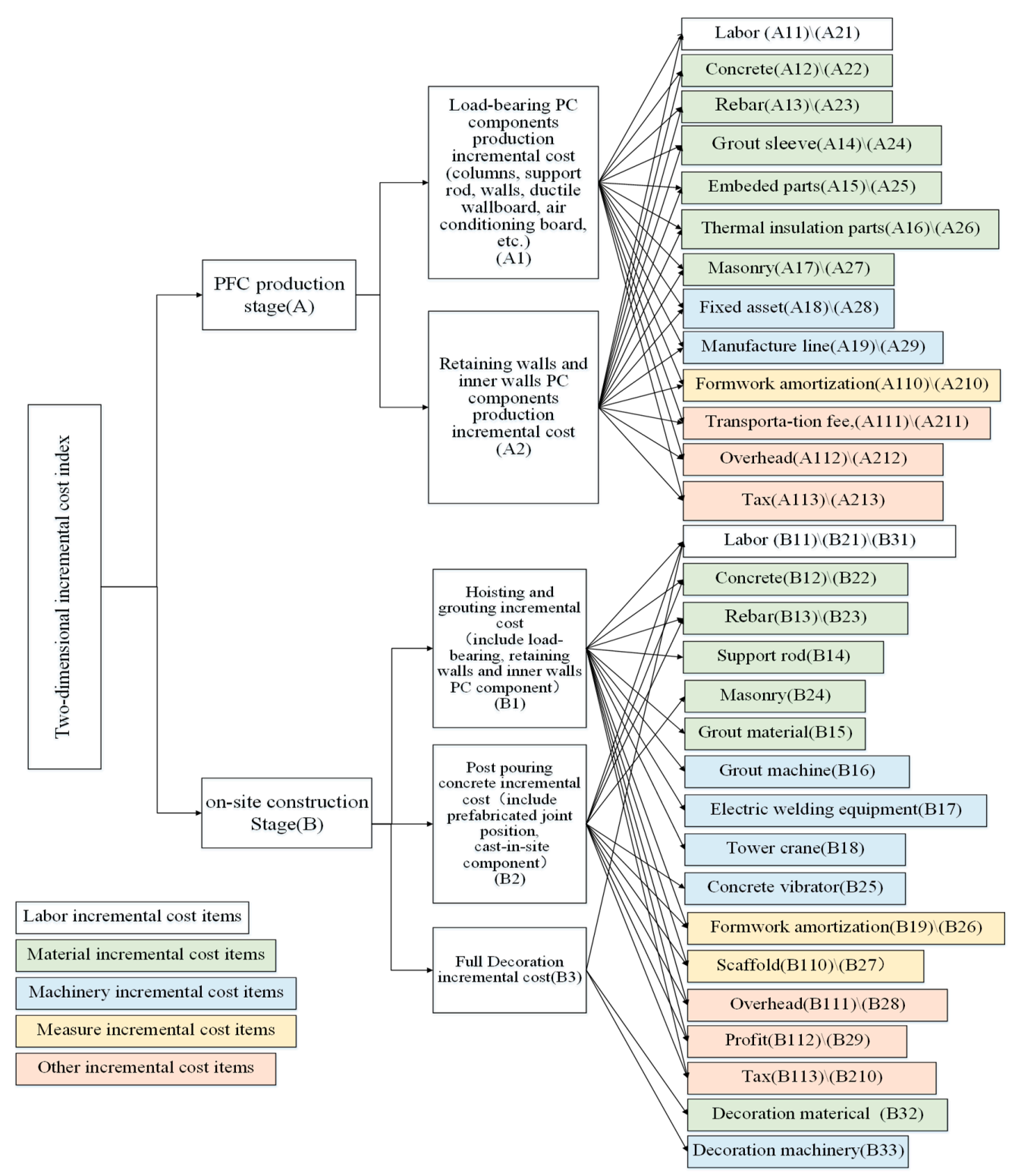

Figure 4. The two-dimensional incremental cost index system.

\subsection{Incremental Calculation Model Based on BIM Simulation}

Before calculation, it is necessary to clarify the method of calculation for the reference and the prefabricated projects. Additionally, the calculation of engineering quantities and the selection of integrated unit prices needs to be attended to, as these are key indicators of the accuracy of the calculation results [43]. The cost calculation model is therefore proposed on the basis of the following principles: (1) accurate calculation of engineering quantities of the reference and the prefabricated projects; (2) detailed setting engineering quota for the two different projects.

\subsubsection{Cost Calculation for Reference Project}

The cost of simulation of the traditional construction is taken as the cost of the reference project. The degree of accuracy to be obtained by BIM models determines the accuracy of engineering quantities and the cost calculation. Common BIM modeling software includes Revit, Bentley and Mechanical. The building information modeling established by Revit has the following advantages over other BIM software: (1) the model accuracy can reach LOD400 (the evaluation standard of building models); (2) it interfaces with calculation software such as Luban and Glodon. Additionally, engineering 
quantity calculation accuracy is obtainable to within $\pm 10 \%$ of acceptable deviation [44]. This study uses prefabricated exterior wall components from the case study to illustrate the evolution of Revit modeling accuracy (see Figure 5).

\begin{tabular}{|c|c|c|c|c|}
\hline $\begin{array}{l}\text { Building } \\
\text { information } \\
\text { modeling } \\
\text { built by } \\
\text { Revit }\end{array}$ & & & & \\
\hline $\begin{array}{l}\text { Degree of } \\
\text { accuracy }\end{array}$ & LOD 100 & LOD 200 & LOD 300 & LOD 400 \\
\hline $\begin{array}{l}\text { Included } \\
\text { building } \\
\text { information }\end{array}$ & $\begin{array}{l}\text { Information } \\
\text { including building } \\
\text { orientation, volume, } \\
\text { and so on }\end{array}$ & $\begin{array}{l}\text { Including the } \\
\text { size,quantity, position, and } \\
\text { other information of the } \\
\text { prefabricated component }\end{array}$ & $\begin{array}{l}\text { Deepened design } \\
\text { model contains } \\
\text { information on } \\
\text { material properties }\end{array}$ & $\begin{array}{l}\text { Finished model contains } \\
\text { reserved holes and } \\
\text { grooves,embedded parts } \\
\text { and so on }\end{array}$ \\
\hline
\end{tabular}

Figure 5. Degree of accuracy of the evolution process of building construction models by Revit.

Common BIM calculation and cost calculation software includes Glodon, Luban, and Tsinghua Sware. Among them, Luban software and Revit are both developed on the AutoCAD platform and the strong compatibility can greatly reduce the accuracy error caused by Revit model import. For example, some frame columns will be identified as concealed columns when the Revit model is imported into Glodon due to the poor compatibility, and a large engineering calculation error will be produced because the calculation rules of frame columns and concealed columns are quite different. Moreover, with the strong compatibility, the buildings models can be bi-directionally imported between Luban software and Revit, software which can greatly improve the efficiency of model modification. This paper refines a Revit building model and calculates the engineering quantity and cost using Luban Architecture and Luban Estimator. It takes the calculation results to be the reference project cost. The calculation process is shown in Figure 6.

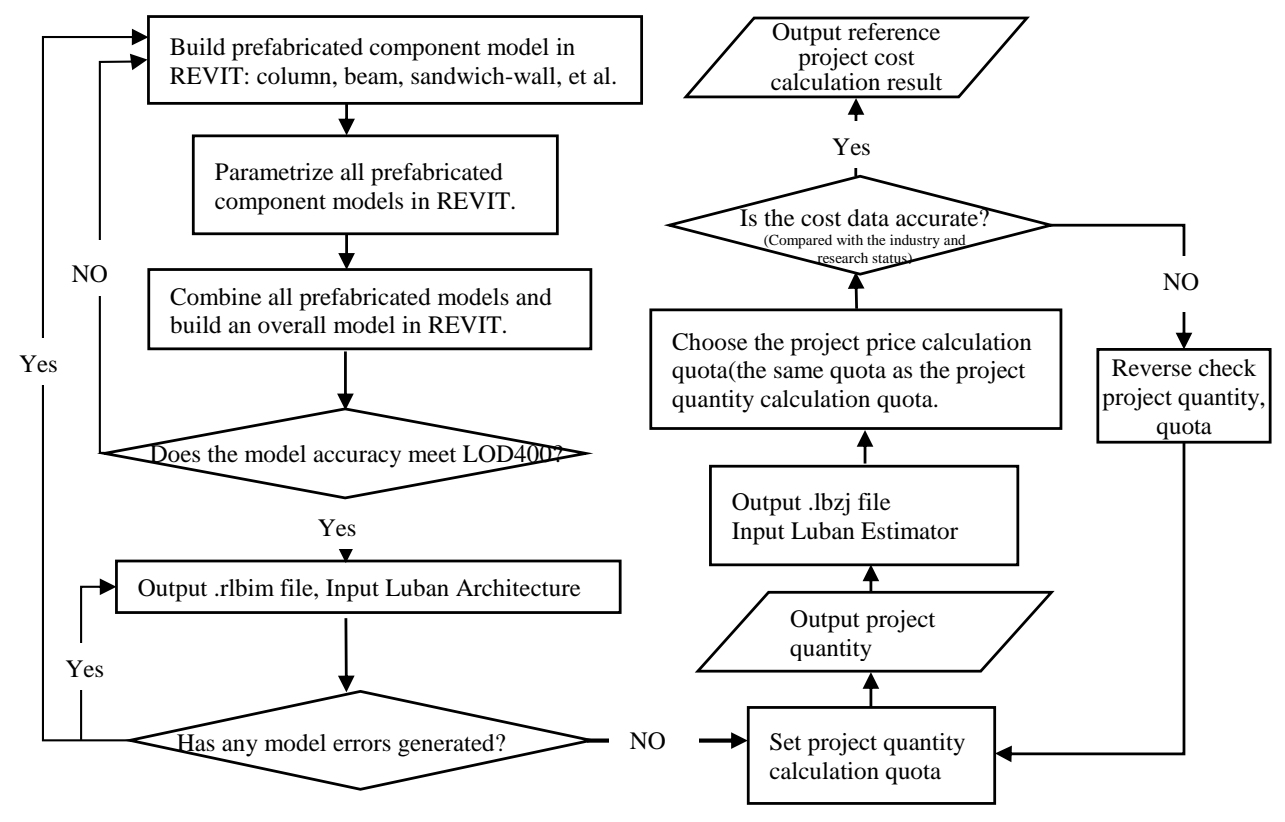

Figure 6. The calculation process of reference project cost. 


\subsubsection{Cost Calculation for Prefabricated Project}

The process of constructing PRBs has five stages. The engineering cost documents for each stage are shown in Figure 7. Among them, the bid estimate document was more accurate than other cost documents before construction [45]. This study therefore takes the PRBs contract cost documents obtained from investigation and research to be the cost of the prefabrication project and compares this to the reference project cost.

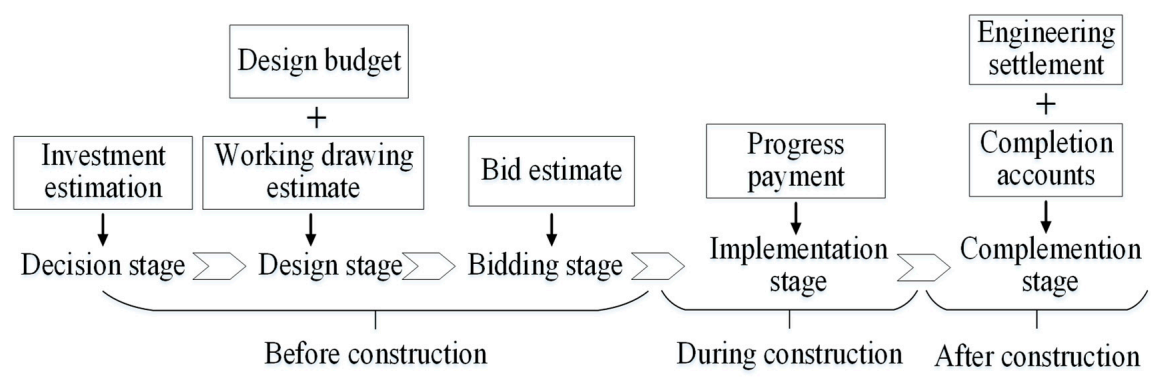

Figure 7. Cost documents in the whole construction stage by type.

\subsubsection{Incremental Cost Calculation Model}

The construction stage incremental cost is the sum of the PFC production stage incremental cost and the on-site construction stage incremental cost. The PFC production incremental cost is equal to the difference between the PFCs production cost of the assembly construction method and the traditional construction method. The on-site construction stage incremental cost is equal to the sum of the hoisting, post-pouring concrete, and full decoration incremental cost. The BIM-based incremental cost calculation model is shown in Figure 8; the calculation formula is shown in Table 3.

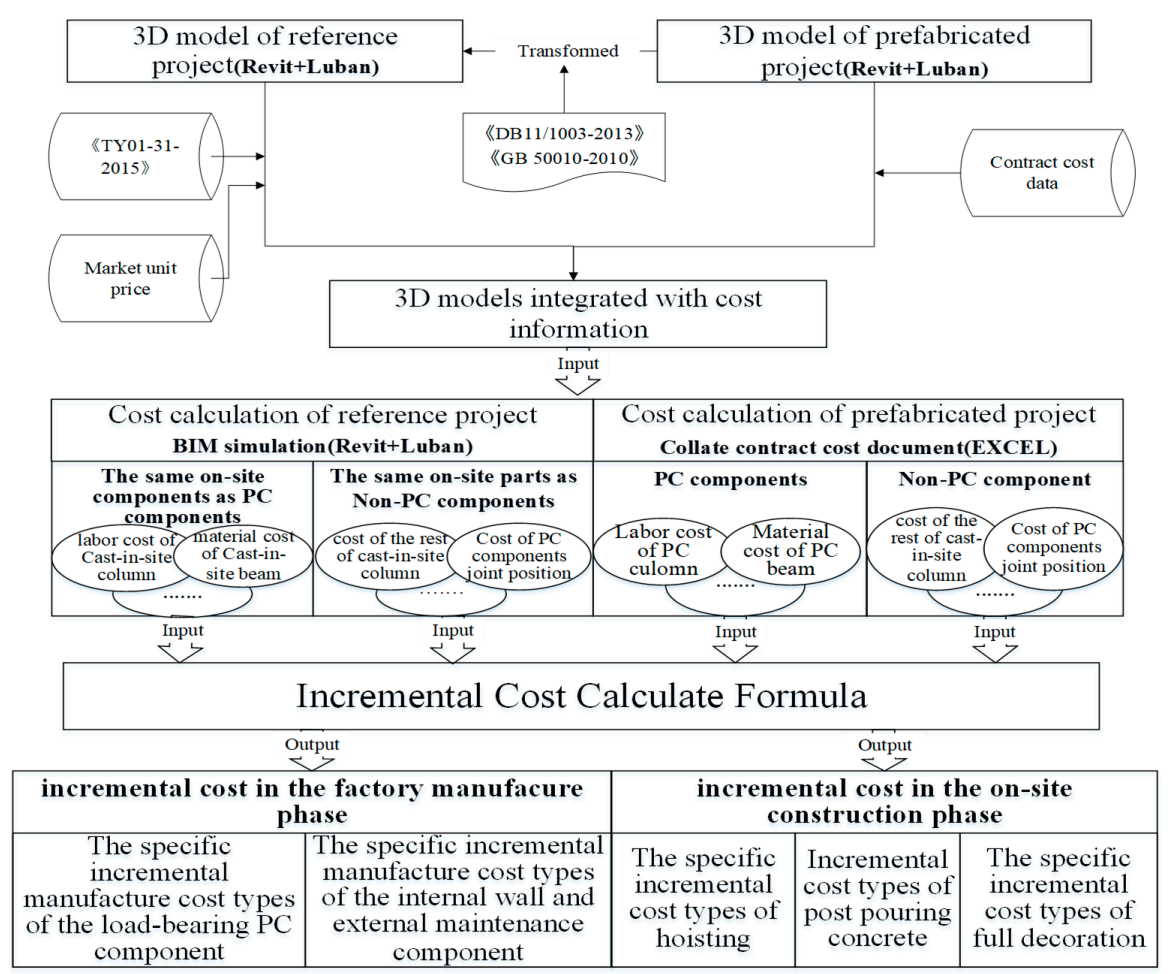

Figure 8. BIM-based incremental cost calculate model. <DB11/1003-2013>, <GB 50010-2010>, $<$ TY01-31-2015> represent Design Specification for Precast Concrete Shear Wall Structure, Code for design of concrete structures and Consumption quota of housing construction and decoration engineering, respectively, which were published by MOHURD. The market unit price represents the average price of building materials of TRB, which was counted by local government departments. 
Table 3. Incremental calculation model based on BIM simulation.

\begin{tabular}{|c|c|c|}
\hline & Formula & Symbolic Interpretation \\
\hline $\begin{array}{l}\text { Factory manufacture stage } \\
\text { Load-bearing PC components } \\
\text { incremental cost (1) }\end{array}$ & $\Delta C_{L}=\sum_{i=1, j=1}^{4,6}\left(C_{P i j}-C_{T i j}\right)$ & $\begin{array}{l}C_{P i j} \text {-prefabrication of the } i \text {-th load-bearing PC component, } \\
j \text {-th cost } \\
C_{T i j} \text {-simulation of on-site pouring the } i \text {-th load-bearing PC } \\
\text { component, } j \text {-th cost }\end{array}$ \\
\hline $\begin{array}{l}\text { Factory manufacture stage } \\
\text { Internal wall and outer } \\
\text { maintenance PC components } \\
\text { incremental cost }(2)\end{array}$ & $\Delta C_{M}=\sum_{k=1, j=1}^{2,6}\left(C_{P k j}-C_{T k j}\right)$ & $\begin{array}{l}C_{P k j}:- \text { prefabrication of the } k \text {-th non-load-bearing PFC, } j \text {-th } \\
\text { cost } \\
C_{T k j} \text { :-simulation of on-site pouring the } k \text {-th Non- } \\
\text { load-bearing PFC, } j \text {-th cost }\end{array}$ \\
\hline $\begin{array}{l}\text { Factory manufacture stage } \\
\text { incremental cost (3) }\end{array}$ & $\Delta C_{H}=\Delta C_{L}+\Delta C_{M}$ & $\begin{array}{l}\Delta C_{L}: \text { load-bearing PFC incremental cost } \\
\Delta C_{M}: \text { non-load-bearing PFC incremental cost }\end{array}$ \\
\hline $\begin{array}{l}\text { On-site construction } \\
\text { stage-hoisting incremental cost (4) }\end{array}$ & $\Delta C_{E}=\sum_{g=1}^{5}\left(C_{P g}-C_{T g}\right)$ & $\begin{array}{l}C_{P g}: g \text {-th hoisting cost of prefabricated construction } \\
C_{T g}: g \text {-th hoisting cost of traditional construction }\end{array}$ \\
\hline $\begin{array}{l}\text { On-site construction } \\
\text { stage-Post-concrete pouring } \\
\text { incremental cost (5) }\end{array}$ & $\Delta C_{T}=\sum_{t=1}^{5}\left(C_{P t}-C_{T t}\right)$ & $\begin{array}{l}C_{P t}: s \text {-th full decoration cost of prefabricated construction. } \\
C_{T t}: t \text {-th post-concrete pouring cost of traditional } \\
\text { construction }\end{array}$ \\
\hline $\begin{array}{l}\text { On-site construction stage-Full } \\
\text { decoration incremental cost (6) }\end{array}$ & $\Delta C_{S}=\sum_{s=1}^{5}\left(C_{P S}-C_{T S}\right)$ & $\begin{array}{l}C_{P_{s}}: s \text {-th full decoration cost of prefabricated construction } \\
C_{T s}: s \text {-th full decoration cost of traditional construction }\end{array}$ \\
\hline $\begin{array}{l}\text { On-site construction stage } \\
\text { incremental cost }(7)\end{array}$ & $\Delta C_{J}=\Delta C_{E}+\Delta C_{T}+\Delta C_{S}$ & $\begin{array}{l}\Delta C_{E}: \text { incremental cost of hoisting } \\
\Delta C_{T}: \text { incremental cost of post-concrete pouring } \\
\Delta C_{S}: \text { incremental cost of full decoration }\end{array}$ \\
\hline Total incremental cost (8) & $\Delta C=\Delta C_{H}+\Delta C_{J}$ & $\begin{array}{l}\Delta C_{H}: \text { factory manufacture stage incremental cost } \\
\Delta C_{J}: \text { on-site construction stage incremental cost }\end{array}$ \\
\hline
\end{tabular}

Note: (1) The $i$-th load-bearing PC components include laminated floors, stairs, balconies, sandwich walls, beams, and columns; (2) the $k$-th Non- load-bearing PC components include internal partitions, prefabricated floor (PCF) panels, and equipment platform boards; (3) post-concrete pouring cost includes the concrete pouring cost of PFCs connection joints and remaining non-PC components cost (cast-in-place beams, cast-in-place columns); (4) the $j$-th cost items include labor cost, material cost, machinery cost, transportation cost, measure cost, and indirect cost;

(5) the $j$-th cost is the product of the engineering quantity and the integrated unit price for each type of expense; (6) simulated on-site pouring concrete cost is obtained from BIM software output and prefabricated construction cost is from corporate contract cost documents.

\section{Case Study}

\subsection{Brief Introduction to the Demonstration Project}

The demonstration project is located in Qingpu District, Shanghai, China. It is a commercial housing project with residences, property management and other supporting services. The building type is an assembled integral shear wall structure. The total ground area is $4015 \mathrm{~m}^{2}$. The main load-bearing PFCs are prefabricated laminated panels, prefabricated stairs, prefabricated balconies, and prefabricated exterior walls. Non-load-bearing PFC includes prefabricated interior walls and PCF panels. The distribution of PFCs is shown in Figure 9. The overall PC degree is 46.34\%, while the standard assembly has 3-8 layers. This prefabricated project is therefore very representative. The PFC production factory is located in Haimen City, Jiangsu, China. It has an automated manufacturing line with mold installation stations, concrete installation and vibration stations, steaming stations, etc., and is located about $240 \mathrm{~km}$ from the construction site. The reference project cost is calculated assuming a $17 \%$ VAT taxation method and taking the local market comprehensive unit price as the labor, materials, and machinery cost calculation of comprehensive unit price. For the reference project, engineering quantity and cost calculation quota, the "Shanghai 2000 Municipal Building and Decoration Project Budget Quota" was used. 


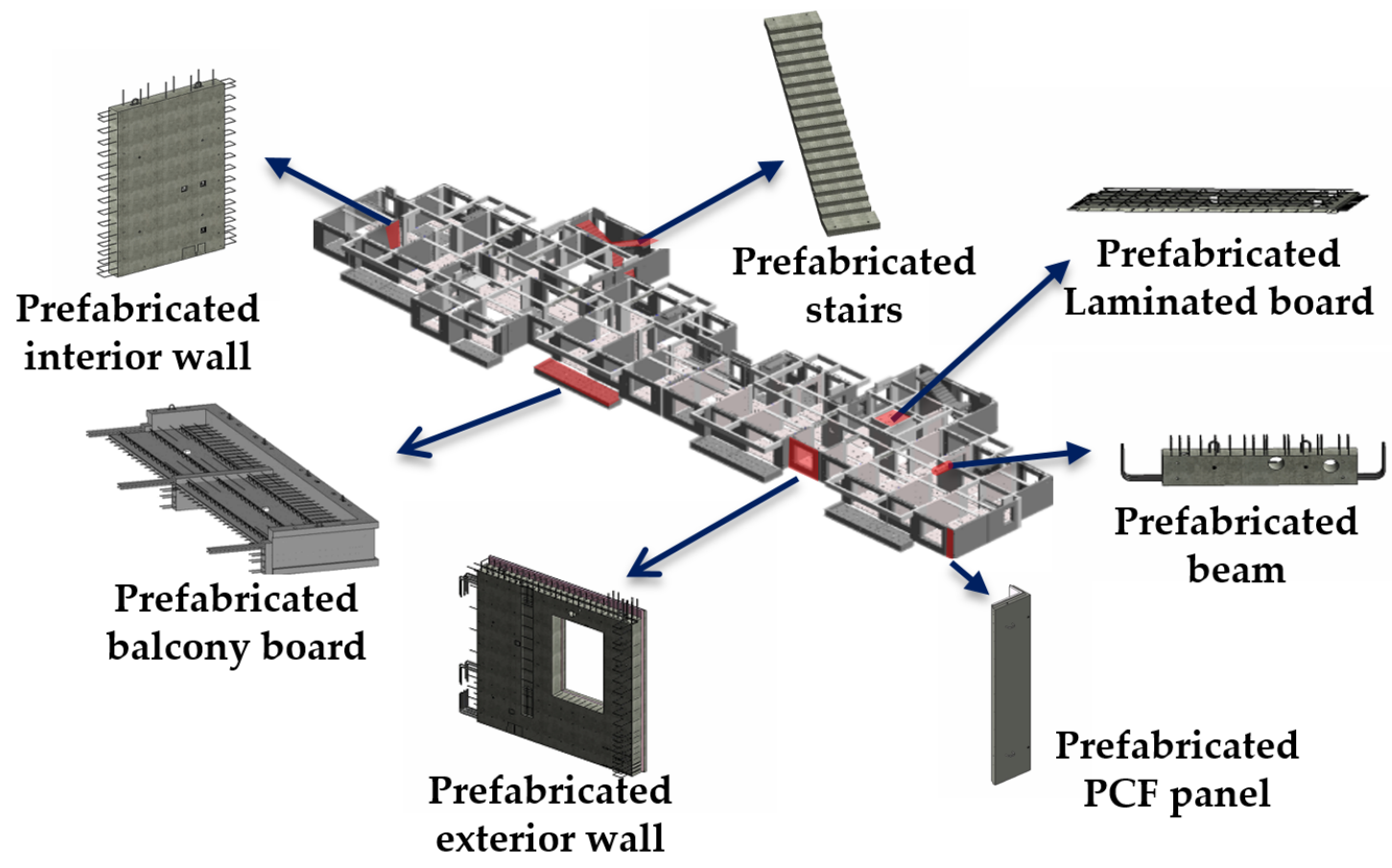

Figure 9. Prefabricated component distribution of the demonstration project standard floor.

\subsection{Incremental Calculation Results of the Whole Construction Period}

The incremental calculation formula proposed in Table 3 was used to calculate the incremental cost index proposed in Figure 4. The cost of the reference project was calculated by BIM simulation. The cost of the prefabrication project was obtained from the PRB construction enterprise and the PFC production factory. Based on the incremental cost index from Figure 4 (A11-A110, A21-A210, B11-B113, B21-B210, B32-B33) and Equation (8) in Table 3, the data sources of prefabricated construction and reference construction cost are shown in Table 4 , and the whole construction incremental cost was first calculated to perform an overall analysis, as shown in Table 5. For detailed analysis, the sources of incremental cost, incremental cost of the PFC production stage and on-site construction stage were respectively calculated based on A11-A113 and A21-A213 in Figure 4, and Formulas (1) and (2) in Table 3, as shown in Tables 6-9.

Table 4. Type and source of incremental for the whole construction stage.

\begin{tabular}{|c|c|c|}
\hline $\begin{array}{ll}\text { Index } & \text { Data Sources } \\
\end{array}$ & $\begin{array}{l}\text { Corporate Cost Document } \\
\text { (Prefabricated Construction Cost) }\end{array}$ & $\begin{array}{c}\text { BIM Simulation } \\
\text { (Reference Construction Cost) }\end{array}$ \\
\hline $\begin{array}{l}\text { Incremental cost of bearing and } \\
\text { non-load-bearing PFC production }\end{array}$ & $\begin{array}{l}\text { PFC design drawings } \\
\text { PFC manufacture plan } \\
\text { PFC cost contract } \\
\text { (From components manufacturers) }\end{array}$ & $\begin{array}{l}\text { PFC model(Revit) types; } \\
\text { PFC engineering quantity types; } \\
\text { (Luban Architecture); } \\
\text { Manufacture cost of each type of PFC } \\
\text { (Luban Estimator) }\end{array}$ \\
\hline $\begin{array}{l}\text { Incremental cost of bearing and } \\
\text { non-load-bearing PFC hoisting }\end{array}$ & $\begin{array}{l}\text { Structural design drawings } \\
\text { Architectural design drawings } \\
\text { Construction organization design } \\
\text { On-site construction cost documents } \\
\text { (from EPC contractor) }\end{array}$ & $\begin{array}{l}\text { Whole building and each type of PFC } \\
\text { model (Revit); } \\
\text { Engineering quantity of post-concrete } \\
\text { pouring parts, decoration and each } \\
\text { type of PFC } \\
\text { (Luban Architecture); } \\
\text { On-site construction cost of } \\
\text { post-concrete pouring parts, } \\
\text { decoration and each type of PFC } \\
\text { (Luban Estimator) }\end{array}$ \\
\hline
\end{tabular}


Table 5. Total incremental cost of the whole construction stage. The cost items refer to the incremental cost index proposed in Figure 4. Labor cost items are A11, A21, B11, B21, and B21. Material cost items are A12-A17, A22-A27, B12-B15, B22-B24, B32. Machinery cost items are A18, A19, A28, A29, B16-B18, B25, and B33. Measurement cost items are A110, A210, B19, B26, B110, and B27. Transportation, indirect, profit and tax cost items respectively refer to A111-A113, A211-A213, B111-B113, and B28-B210. The results are calculated using Equation (8) (proposed in Table 3) (yuan $/ \mathrm{m}^{2}$ ).

\begin{tabular}{|c|c|c|c|c|c|c|c|c|c|}
\hline \multicolumn{10}{|c|}{ Construction Stage } \\
\hline Cost Items & & Labor & Material & Machinery & Measure & Transportation & Indirect & Profit and Tax & Total \\
\hline \multicolumn{2}{|c|}{ PFC production } & -85.15 & 81.26 & 97.59 & 167.09 & 58.95 & 53.81 & 107.28 & 480.82 \\
\hline \multirow{3}{*}{$\begin{array}{c}\text { On-site } \\
\text { construction }\end{array}$} & $\begin{array}{c}\text { Hoisting and } \\
\text { grouting }\end{array}$ & -48.90 & 132.52 & 133.85 & - & - & -25.63 & 2.79 & 194.61 \\
\hline & $\begin{array}{c}\text { Post-concrete } \\
\text { pouring }\end{array}$ & -2.01 & -5.89 & -1.67 & -3.34 & - & -1.12 & -1.18 & -15.22 \\
\hline & Full decorati-on & -2.62 & -2.13 & -0.91 & - & - & - & - & -5.67 \\
\hline \multicolumn{2}{|c|}{ Total } & -138.69 & 205.77 & 228.86 & 163.74 & 58.95 & 27.05 & 108.89 & 654.58 \\
\hline
\end{tabular}

Table 6. Incremental cost of the prefabricated PFC production stage. The cost items refer to the incremental cost index proposed in Figure 4. The results of load-bearing PFCs are calculated using indicators A11-A113 and Equation (1) (proposed in Table 3) (yuan $/ \mathrm{m}^{2}$ ). The results of internal wall and outer maintenance PFCs are calculated using indicators A21-A213 and Equation (2) (proposed in Table 3) (yuan $\left./ \mathrm{m}^{2}\right)$.

\begin{tabular}{|c|c|c|c|c|c|c|c|c|}
\hline \multirow[b]{2}{*}{ Cost Items } & \multirow[t]{2}{*}{ PFC Types } & \multicolumn{4}{|c|}{ Load-Bearing PFCs } & \multicolumn{2}{|c|}{$\begin{array}{l}\text { Internal Wall and Outer } \\
\text { Maintenance PFCs }\end{array}$} & \multirow[t]{2}{*}{ Total } \\
\hline & & $\begin{array}{l}\text { Laminated } \\
\text { Floor }\end{array}$ & Stairs & Balcony & $\begin{array}{l}\text { Sandwich } \\
\text { Wall }\end{array}$ & $\begin{array}{c}\text { Internal } \\
\text { Wall }\end{array}$ & PCF Panel & \\
\hline & Labor & -192.348 & -64.71 & -172.72 & -138.58 & -29.12 & -147.279 & -744.76 \\
\hline \multirow{6}{*}{ Material } & Steer bar & 115.1854725 & 13.17 & 10.06 & 15.60 & 15.30 & 15.25 & 184.57 \\
\hline & Concrete & 119.80 & 14.52 & 52.64 & 15.21 & 45.25 & 15.27 & 262.69 \\
\hline & Grouting sleeve & - & - & - & 84.99 & 170.81 & - & 255.80 \\
\hline & Embedded parts & 39.59 & 59.41 & 35.48 & 56.22 & 62.10 & 80.12 & 332.92 \\
\hline & Insulation material & - & - & - & 12.92 & - & 22.04 & 34.96 \\
\hline & Masonry & - & - & - & -35.95 & -324.22 & - & -360.172 \\
\hline \multirow{2}{*}{\multicolumn{2}{|c|}{$\begin{array}{c}\text { Formwork amortization } \\
\text { Machinery }\end{array}$}} & 153.46175 & 184.95 & 369.18 & 300.01 & 252.02 & 201.74 & 1461.36 \\
\hline & & 51.98 & 113.15 & 297.67 & 142.52 & 154.99 & 93.19 & 853.5 \\
\hline \multicolumn{2}{|c|}{ Transportation } & 47.50 & 91.74 & 72.20 & 90.21 & 94.45 & 119.50 & 515.6 \\
\hline \multicolumn{2}{|c|}{ Overhead } & 66.75 & 68.96 & 67.44 & 83.87 & 74.09 & 109.55 & 470.66 \\
\hline \multicolumn{2}{|r|}{ Tax } & 94.88 & 171.82 & 201.04 & 179.64 & 187.60 & 103.37 & 938.36 \\
\hline \multicolumn{2}{|r|}{ Total } & 496.79 & 653.02 & 932.99 & 806.72 & 703.25 & 612.76 & 4205.53 \\
\hline
\end{tabular}

Table 7. Incremental cost of on-site assembling stage-hoisting. The cost items refer to the incremental cost index proposed in Figure 4. The results of load-bearing PFCs are calculated using indicators A11-A113 and Equation (4) (proposed in Table 3) (yuan $/ \mathrm{m}^{3}$ ). The results of internal wall and outer maintenance PFCs are calculated using indicators A21-A213 and Equation (4) (proposed in Table 3) (yuan $\left./ \mathrm{m}^{3}\right)$.

\begin{tabular}{|c|c|c|c|c|c|c|c|c|}
\hline \multirow[b]{2}{*}{ Cost Items } & \multirow[t]{2}{*}{ PFC Types } & \multicolumn{4}{|c|}{ Load-Bearing PFCs } & \multicolumn{2}{|c|}{$\begin{array}{l}\text { Internal Wall and Outer } \\
\text { Maintenance PFCs }\end{array}$} & \multirow[t]{2}{*}{ Total } \\
\hline & & $\begin{array}{l}\text { laminated } \\
\text { Floor }\end{array}$ & Stair & Balcony & $\begin{array}{l}\text { Sandwich } \\
\text { Wall }\end{array}$ & $\begin{array}{c}\text { Internal } \\
\text { Wall }\end{array}$ & PCF Panel & \\
\hline & Labor & -90.40 & -79.23 & -64.08 & -67.36 & -65.63 & -61.04 & -427.74 \\
\hline \multirow{2}{*}{ Material } & Support rod & 165.76 & 129.19 & 211.48 & 216.61 & 214.28 & 168.28 & 925.60 \\
\hline & Grouting material & - & - & - & 114.33 & 119.16 & - & 233.49 \\
\hline \multirow{3}{*}{ Machinery } & Grouting Machinery & - & - & - & 29.70 & 49.35 & - & 79.05 \\
\hline & Welding equipment & 37.17 & - & 30.74 & - & - & - & 67.91 \\
\hline & Tower crane & 101.54 & 172.19 & 239.59 & 131.27 & 109.45 & 89.68 & 1023.72 \\
\hline & Overhead & -26.06 & -29.06 & -37.47 & -53.99 & -61.01 & -16.62 & -224.21 \\
\hline & Profit & -23.56 & -20.04 & -29.66 & -50.97 & -75.87 & -22.84 & -222.94 \\
\hline & Tax & 27.96 & 29.42 & 59.60 & 54.33 & 49.25 & 26.77 & 247.33 \\
\hline & Total & 192.41 & 202.47 & 410.20 & 373.92 & 338.98 & 184.23 & 1702.21 \\
\hline
\end{tabular}


Table 8. On-site assembly construction stage incremental cost post-concrete pouring. The results of assembly construction are calculated using the incremental cost index proposed in Figure 4 (B11-B1113, B21-B210) and Formula (5) (proposed in Table 3) (yuan $/ \mathrm{m}^{2}$ ).

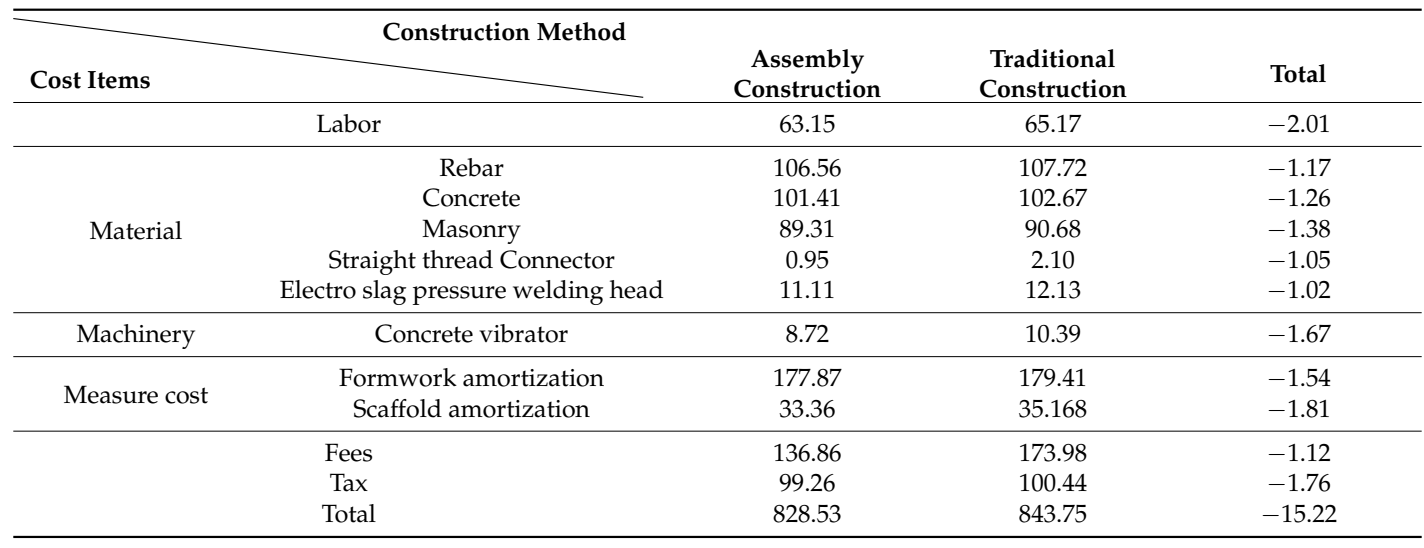

Table 9. On-site assembly construction stage incremental full-cost decoration. The results are calculated using indicators proposed in Figure 4 (B31, B32, B33) and Equation (6) (proposed in Table 3) (yuan/m²).

\begin{tabular}{|c|c|c|c|c|}
\hline Cost Items & Construction Method & $\begin{array}{c}\text { Assembly } \\
\text { Construction }\end{array}$ & $\begin{array}{l}\text { Traditional } \\
\text { Construction }\end{array}$ & Total \\
\hline \multirow{5}{*}{ Labor } & Floor decoration & 12.81 & 13.37 & -0.56 \\
\hline & Wall decoration & 70.57 & 71.25 & -0.69 \\
\hline & Ceiling decoration & 3.10 & 3.55 & -0.45 \\
\hline & Baseboard decoration & 0.21 & 0.63 & -0.42 \\
\hline & Roof decoration & 7.50 & 8.01 & -0.51 \\
\hline \multirow{5}{*}{$\begin{array}{c}\text { Material } \\
\text { and machinery }\end{array}$} & Floor decoration & 21.28 & 21.91 & -0.63 \\
\hline & Wall decoration & 35.63 & 36.55 & -0.92 \\
\hline & Ceiling decoration & 1.92 & 2.43 & -0.51 \\
\hline & Baseboard decoration & 0.07 & 0.50 & -0.43 \\
\hline & Roof decoration & 16.76 & 17.32 & -0.55 \\
\hline \multicolumn{2}{|r|}{ Total } & 169.85 & 175.51 & -5.66 \\
\hline
\end{tabular}

\subsection{Incremental Cost Calculation Results Analysis}

\subsubsection{Incremental Cost Analysis of the Whole Construction Stage}

Overall, the PRB construction cost is 654.58 yuan $/ \mathrm{m}^{2}$ higher than for TRBs. The cost of post-concrete pouring technology and full decoration technology cost are the reduction costs. The costs of PFC production and grouting and hoisting technology increased, among which, the PFC production cost increased the most. The proportion of incremental cost and cost item in the whole construction stage $\mathrm{s}$ is shown in Figure 10.

Figure 9 shows that the machinery incremental cost for the entire construction process is 228.86 yuan $/ \mathrm{m}^{2}$. This accounts for $35 \%$. The incremental cost of materials, measurements, and profits and taxes are 205.76, 163.74 and 108.89 yuan $/ \mathrm{m}^{2}$, respectively, which account for $31.4 \%, 25 \%$ and $16.6 \%$ respectively. The labor cost is decremented: -138.69 yuan $/ \mathrm{m}^{2}$.

The machinery incremental cost consists of manufacture line, tower cranes for hoisting, and grouting costs. China is in the early stages of its development of PRB, so PFC production and construction enterprises still face many challenges, such as the large initial investment required and the lack of familiarity with installation technologies needed at construction sites. Furthermore, given the increase in the number of PC component orders, the industry must also confront obstacles to the improvement of assembly construction technology, the depreciation of manufacturing lines and tower cranes and other incremental costs. 


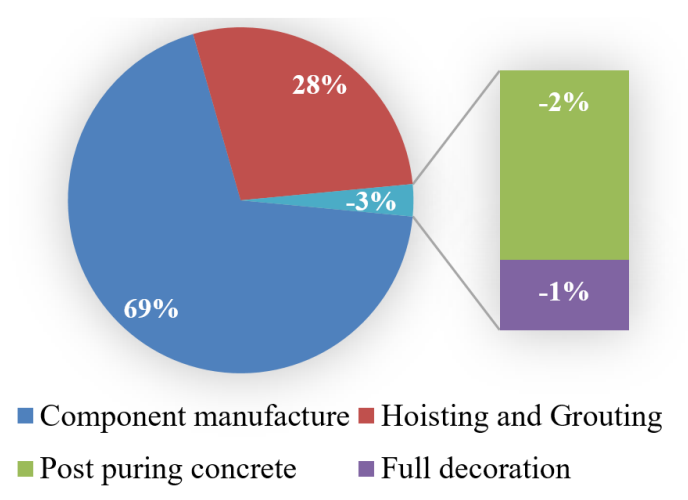

(a)

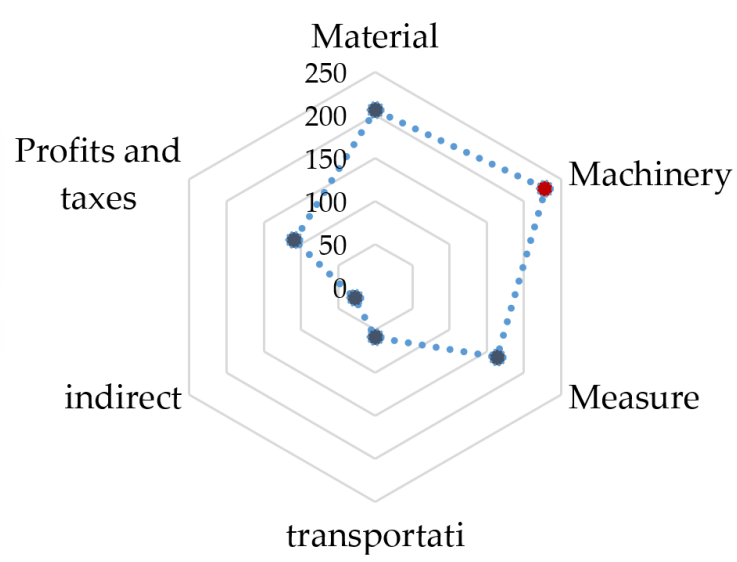

(b)

Figure 10. Proportion of the whole construction stage incremental cost and cost items. The analysis results are based on the incremental cost calculation data shown in Table 4 (yuan $/ \mathrm{m}^{3}$ ). (a) represents the incremental cost ratio of the prefabricated technologies, and (b) represents the incremental cost rankings of different cost items.

\subsubsection{Incremental Cost Analysis of the PFC Production Stage}

In this case, the incremental cost of PFC production is $4205.52 \mathrm{yuan} / \mathrm{m}^{3}$. Analysis of the PFC production stage incremental cost and of cost items for each PFC type can be found in Figure 11. The manufacturing technology costs for each kind of PC component are as follows: The incremental cost of prefabricated balcony manufacture is the highest, at $932.99 \mathrm{yuan} / \mathrm{m}^{3}$, which is $23 \%$ of the total incremental manufacture cost. This is followed by the incremental manufacture cost of sandwich outer and inner walls, which are respectively 806.72 yuan $/ \mathrm{m}^{3}$ and 703.25 yuan $/ \mathrm{m}^{3}$, accounting for $20 \%$ and $17 \%$ of the total incremental manufacture cost, respectively. The incremental cost of prefabricated laminated floor manufacture is the lowest, at $496.79 \mathrm{yuan} / \mathrm{m}^{3}$, accounting for $11.1 \%$ of the total incremental manufacture cost.

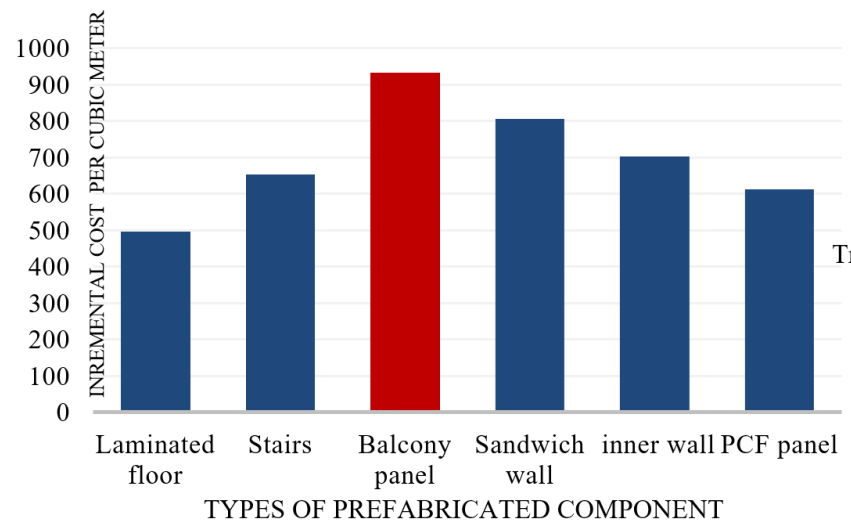

(a)

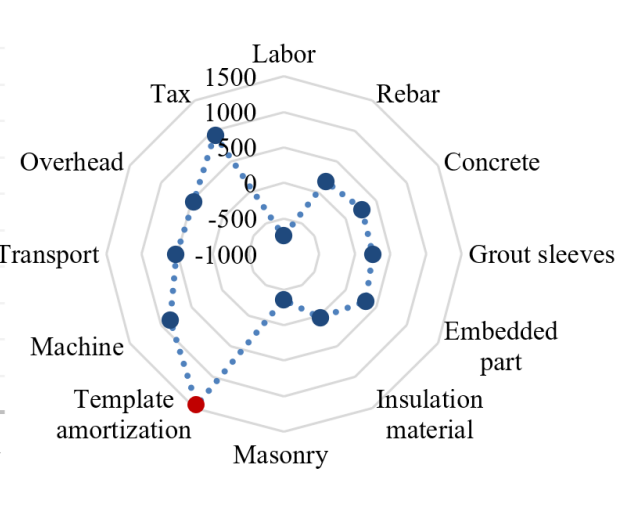

(b)

Figure 11. Analysis of the PFC production stage incremental cost and cost items. The analysis results are based on the incremental cost calculation data in Table $5\left(\mathrm{yuan} / \mathrm{m}^{3}\right)$. (a) represents the incremental cost rankings of factory producing incremental cost of different PFCs, and (b) represents the incremental cost rankings of different cost items of PFC production.

The amortization incremental cost for PFC production templates increased by a maximum of 1461.41 yuan $/ \mathrm{m}^{3}$. This is followed by the incremental costs for taxes, machinery, and transportation, which were respectively $938.39,853.50$ and 515.61 yuan $/ \mathrm{m}^{3}$. The labor cost is the reduction cost, followed by overheads, which were 744.76 yuan $/ \mathrm{m}^{3}$ and $470.65 \mathrm{yuan} / \mathrm{m}^{3}$, respectively. 
Recently, China's demographic dividend has decreased year on year. Since building components began to be produced in factories rather than constructed on-site, automated manufacture lines have replaced certain manual operations, such as components handling, concrete pouring, polishing, etc. This has increased the efficiency of the distribution of manufactures, improved work efficiency, reduced labor cost, and promoted the sustainable development of the construction industry. However, in order to meet split design requirements, the need for rebar and concrete volumes for prefabricated laminated floors, prefabricated sandwich exterior walls, and other components has increased, as has the need for new cost items such as embedded parts and grouting sleeves. This means that the overall cost of the PC components factory manufacture has increased. Currently, the degree of standardization of fabricated buildings in China is relatively low and the components are sold as products, which greatly increases template amortization fees and taxes. However, design difficulties will be overcome and the industrial chain is constantly improving. Incremental cost will therefore gradually decline.

\subsubsection{Incremental Cost Analysis of the on-Site Assembly Construction Stage}

The incremental cost of the on-site construction stage has three elements: the hoisting and grouting incremental cost, the post-cast concrete incremental cost, and the full decoration incremental cost. The incremental hoisting and grouting cost is the highest at $1702.2 \mathrm{yuan} / \mathrm{m}^{3}$. The post-cast concrete and full decoration costs are negative costs, and are respectively -15.22 and -5.67 yuan $/ \mathrm{m}^{2}$. The total incremental cost of hoisting and grouting and the cost of each specific item of the PFCs are shown in Figure 12.

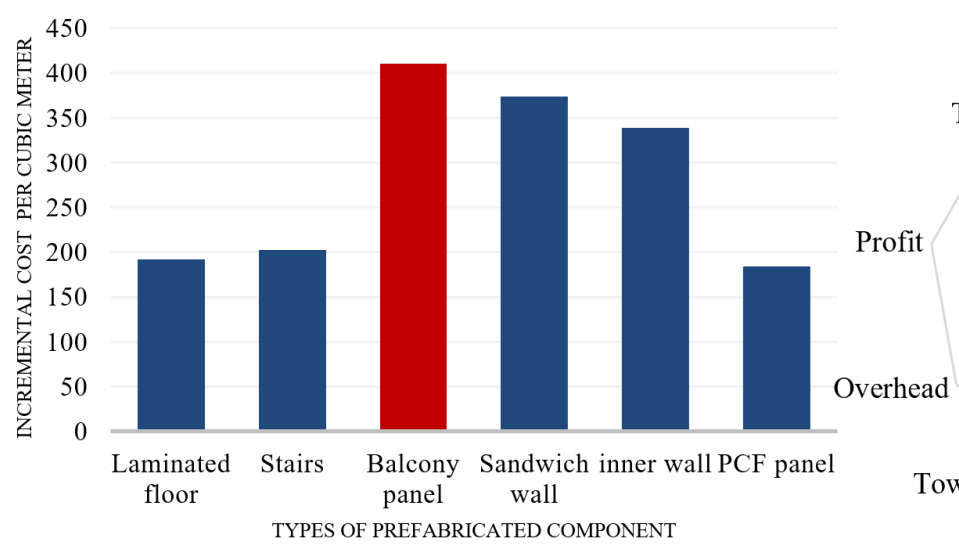

(a)

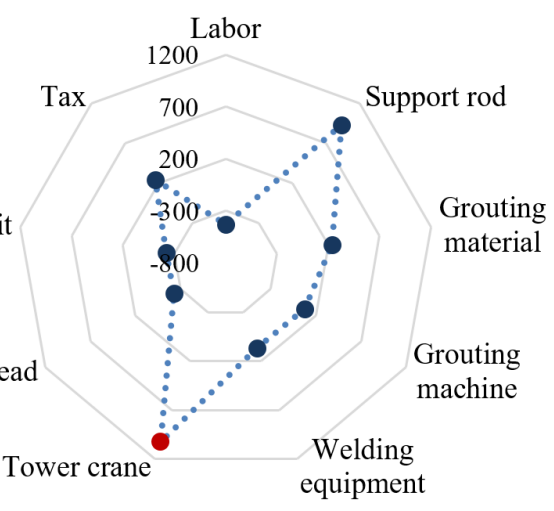

(b)

Figure 12. Incremental cost and cost items analysis of each type of hoisting and grouting PFC. The analysis results are based on incremental cost calculation data in Table 6 (yuan $/ \mathrm{m}^{3}$ ). (a) represents the incremental cost rankings of on-site assembling incremental cost of different PFCs, and (b) represents the incremental cost rankings of different cost items of PFC on site assembling.

The costs for the hoisting and grouting of PC components types are as follows: the increased cost of prefabricated balconies is the highest, at 410.20 yuan $/ \mathrm{m}^{3}$, accounting for $24 \%$ of the total incremental cost of hoisting and grouting. This is followed by sandwich wall and inner wall costs, which are respectively 373.91 and 338.98 yuan $/ \mathrm{m}^{3}$, accounting for $21.9 \%$ and $19.9 \%$ of the total incremental cost of hoisting and grouting respectively. PCF board incremental cost is at least $184.23 \mathrm{yuan} / \mathrm{m}^{3}$, accounting for $10.8 \%$ of the total incremental cost of hoisting and grouting. This is followed by the costs of prefabricated laminated floors and prefabricated stairs, which are respectively 192.41 and 202.48 yuan $/ \mathrm{m}^{3}$, accounting for $11.4 \%$ and $12 \%$ of the total incremental cost of hoisting and grouting respectively.

Of the incremental costs, the machinery is the highest, at $1023.72 \mathrm{yuan} / \mathrm{m}^{3}$, accounting for $60 \%$ of the total hoisting and grouting incremental cost. This is followed by the material incremental cost, at 
925.56 yuan $/ \mathrm{m}^{3}$, accounting for $54 \%$ of the total hoisting and grouting incremental cost. The labor cost, overhead and profit are reduction costs.

Hoisting and grouting machinery incremental cost consists of tower crane and grouting equipment cost, etc. Due to the great size and fragility of PFCs, and problems resolving difficulties such as aligning reserved holes and determining slurry, the hoisting and grouting machinery incremental cost remains the highest. However, with the increase in the proficiency of hoisting work and the accumulation of experience with hoisting and grouting components, it is very conceivable that the hoisting machinery incremental cost will gradually decline.

The cost of post-pouring concrete consists of the concrete pouring cost of PFC joints and the remaining non-PFC parts of buildings. Given the fall in on-site wet work, the cost of post-pouring concrete is the reduction cost, which is $-61,095.22$ yuan. The PFCs are polished during factory manufacture, which can reduce the need for decorative work. Additionally, the prefabricated sandwich external walls have heat-insulating materials added at the factory, which can eliminate the need to insulate them at the construction site. The full decoration cost is thereby reduced to 22,733.27 yuan. The analysis of the post-pouring concrete and full decoration negative cost is shown in Figure 13.

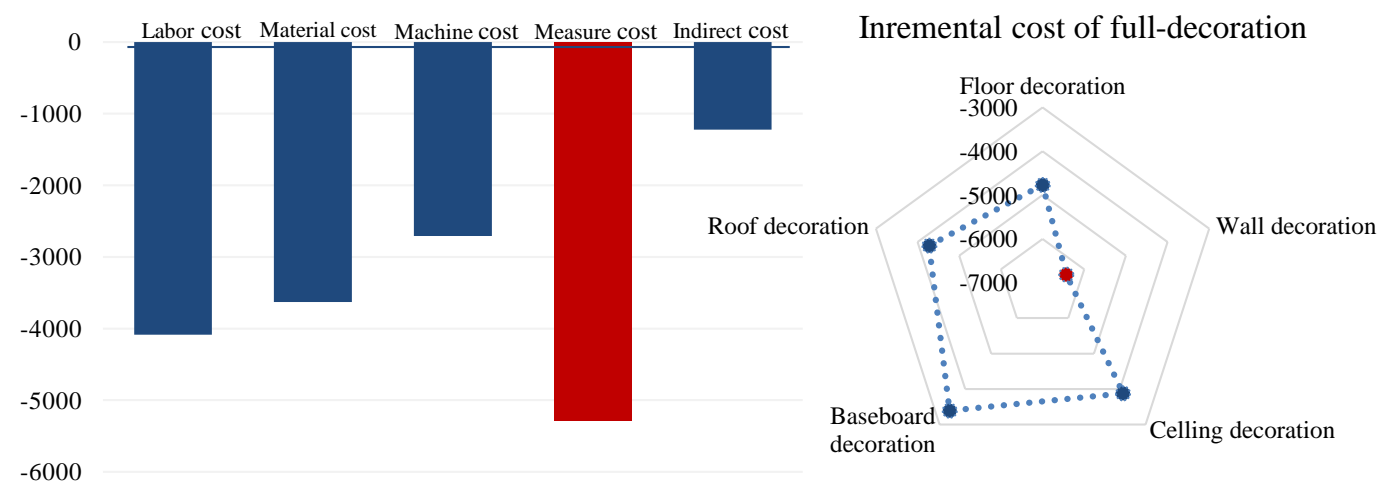

(a)

(b)

Figure 13. Analysis of incremental cost of the post pouring concrete and full decoration stage. The analysis results are based on the incremental cost calculation data in Tables 6 and 8 (yuan). (a) represents the incremental cost rankings of different cost items of post-pouring concrete technology, and (b) represents the incremental cost rankings of different full-decoration technologies.

\section{Conclusions}

In order to produce a more comprehensive analysis of the incremental cost of PRB, and improve the applicability of the incremental cost composition items of the whole construction stage, the most recent and authoritative PRB policy, CQ and EC are introduced. This study adopts combined qualitative and quantitative methods, those of fishbone analysis and semi-structured interview. This is done to generate a two-dimensional incremental cost index system which considers the incremental costs of all kinds of cost items and assembly technologies. A quantitative incremental cost calculation model is also developed using the BIM simulation method in order to obtain accurate calculations results. To verify the objectivity and applicability of the study results, this study also conducted a case study of an existing PRB. The following conclusions were obtained:

The composition of the whole construction stage incremental cost items includes: load-bearing and retaining walls and inner walls PFC production incremental costs, which includes labor incremental cost, material incremental cost (steer bar, concrete, grout sleeves, embedded parts, and thermal insulation parts), machinery incremental costs (fixed asset cost and manufacture line cost), measure incremental cost (formwork amortization cost), and other incremental costs (transportation fees and tax). In the on-site construction stage, the incremental cost items include: hoisting and grouting incremental cost (labor, concrete, rebar, support rod, grout material, grout machine, electric welding equipment, tower crane, formwork amortization, scaffold, overhead, profit, and tax), post pouring 
concrete material cost (labor, concrete, rebar, masonry, concrete vibrator, formwork amortization, scaffold, overhead, profit, and tax), and full decoration incremental cost (labor, decoration material and decoration machinery).

The incremental cost calculation for the PRB case based on BIM simulation is $654.58 \mathrm{yuan} / \mathrm{m}^{2}$, which accounts for $43.7 \%$ of the total construction cost. This calculation result is within the range of national average PRB incremental estimation results (incremental cost accounts for $20-50 \%$ of total construction cost [46]). Due to the complex structure and lower sales, the main incremental production cost can be associated with the production of prefabricated balconies. The materials and machinery cost (grout materials, support rods, grouting machines, electric welding equipment, and tower cranes) of hoisting and grouting at the on-site construction stage also increased because of inadequate technology and a lack of experience. By contrast, as a result of indirect benefits from materials (formwork, scaffold and decoration material) and labor-saving, the costs of post-concrete pouring technology and the full decoration technology at the on-site construction stage, decreased considerably. Moreover, the labor cost and overheads for the entire construction stage also decreased because of improvements in construction standardization and mechanization.

With the growing popularity of PRBs across China, and the continuing progress of assembly technology, incremental cost will naturally decrease. At the same time, there will be obvious environmental benefits. The following suggestions based on the practices of developed countries can be adopted to alleviate the current high construction incremental cost [47-49]: (1) standardized design specifications for PRBs, improved traditional split design patterns and improved standardization to reduce the formwork amortization cost; (2) the strengthening of policy support by local governments across China and the elimination of the system of duplicated taxation for PFCs, in order to reduce the sale price of PFCs; (3) the formation of a mature construction technology system in consideration of the construction habits of labor, thereby reducing tower crane and support materials costs. Therefore, further study should be initiated focusing on the relational functions for incremental cost items and its influence factors (i.e., assembly rate, incentive policies, and assembly technologies) to explore the validity of the above-mentioned suggestions, and determine the best way to reduce PRB construction cost.

Author Contributions: Y.Q. and S.C. conceived and designed the research concept; S.C. and K.Q. analyzed the data; S.C. wrote the manuscript; Y.Q. modified the manuscript, Y.J. and Y.Q., contributed to the research concept with theoretical guidance and advice.

Funding: This work was partially supported by the National Key Research and Development Program of China through the project, "Industrial Building Lifetime Performance and Level Assessment Technology and Standards" (2016YFC0701806), the Ministry of Science and Technology of the People's Republic of China through the project, "Comprehensive Supervision Platform and Demonstration of Industrialization Construction Evaluation" (2016YFC0701810).

Conflicts of Interest: The authors declare no conflict of interest.

\section{References}

1. Economic and Social Development Statistical Communique of People's Republic of China. 2017. Available online: http:/ / www.stats.gov.cn/tjsj/zxfb/201802/t20180228_1585631.html (accessed on 28 February 2018).

2. Notice of the State Council on Printing and Distributing the National Population Development Plan (2016-2030). Available online: http:/ / www.gov.cn/zhengce/content/2017-01/25/content_5163309.html (accessed on 25 January 2017).

3. In August, the National Economy Maintained an Overall Stable, Stable and Positive Development Trend. Available online: http://www.stats.gov.cn/tjsj/zxfb/201809/t20180914_1622877.html (accessed on 14 November 2018).

4. Material Waste in the China Construction Industry: Minimization Strategies and Benefits of Recognition. Available online: http://www.ijee.ieefoundation.org/vol5/issue6/IJEE_09_v5n6.pdf (accessed on 30 September 2016). 
5. Li, J.; Ding, Z.; Mi, X.; Wang, J. A Model for Estimating Construction Waste Generation Index for Building Project in China. Resour. Conserv. Recyc. 2013, 74, 20-26. [CrossRef]

6. Pedro, S.; Manuela, G.A.; Luís, B.; Vasco, M. Development of prefabricated retrofit module towards nearly zero energy; buildings. Energy Build. 2013, 56, 115-125. [CrossRef]

7. Guiding Opinions of the General Office of the State Council on Vigorously Developing Prefabricated Buildings. Available online: http://www.gov.cn/zhengce/content/2016-09/30/content_5114118.html (accessed on 30 November 2016).

8. Chen, Y.; Cao, X.; Wei, B. Study on the Influence of Value-added Tax on the Project Cost of Prefabricated Buildings. Econ. Bus. Manag. 2017. [CrossRef]

9. Hong, J.; Shen, Q.; Li, Z.; Zhang, B.; Zhang, W. Barriers to Promoting Prefabricated Construction in China: A Cost-Benefit Analysis. J. Clean. Prod. 2018, 172. [CrossRef]

10. Arif, M.; Egbu, C. Making a case for offsite construction in China. Eng. Constr. 2010, 17, 536-548. [CrossRef]

11. Tomas, U.G. Development and Efficiency of Prefabricated Building Components. Smart Home 2016, 10, 85-94. [CrossRef]

12. Cost Reduction through Cost Effective Construction Techniques. Available online: https://www.ijsr.net/ archive/v4i2/SUB151760.pdf (accessed on 3 February 2015).

13. Elvira, A.; Jesús, C.; Germán, P.; Guillermo, R.-D. A multi-domain incremental analysis engine and its application to incremental resource analysis. Theor. Comput. Sci. 2015, 585, 91-114. [CrossRef]

14. Prefabrication: A Lean Strategy for Value Generation in Construction. Available online: https:/ /iglcstorage.blob.core.windows.net/papers/attachment-b2d89667-269f-40cd-a20e-04f2f9082a98. pdf (accessed on 10 July 2006).

15. Diana, L.; Thomas, M.F. Analysis of costs and benefits of panelized and modular prefabricated homes. Procedia Eng. 2016, 145, 1291-1297. [CrossRef]

16. Dorina, N.I.; Sebastian, G.M.; Oana, N. Thermal Analysis of a Structural Solution for Sustainable, Modular and Prefabricated Buildings. Mater. Sci. Eng. 2017, 46, 17-19. [CrossRef]

17. Qi, L.; Xu, J. Analysis of Incremental Costs of Housing Industrialization and Its Resolution Approach. Build. Econ. 2015, 12, 5-8. [CrossRef]

18. Yu, W. Discussion on cost control and countermeasure analysis of prefabricated buildings. Low Temp. 2018, 8, 125-128. [CrossRef]

19. Nick, B.; Ron, W. Drivers, constraints and the future of offsite manufacture in Australia. Constr. Innov. 2013, 9, 72-83. [CrossRef]

20. Lihong, L.; Zuhai, X.; Xin, F. Cost Analysis of Civil Engineering for Assembled Integral Buildings. Build. Econ. 2014, 35, 63-67. [CrossRef]

21. Guangming, W.; Zhen, W. Incremental Cost Analysis and Countermeasures of Assembled Concrete Building. Archit. Econ. 2017, 38, 15-21. [CrossRef]

22. Mao, C.; Xie, F.; Hou, L.; Wu, P.; Wang, J.; Wang, X. Cost analysis for sustainable off-site construction based on a multiple-case study in China. Habitat Int. 2016, 57, 215-222. [CrossRef]

23. Lu, J.; Junbo, R. Research on Incremental Cost Control Method of Assembled Integral Shear Wall Structure. Sci. Technol. 2017, 29, 470-475. [CrossRef]

24. Talking about the Economics of PC and Related Problems. Available online: https://wenku.baidu.com/ view / c695f476a88271fe910ef12d2af90242a895abef.html (accessed on 15 August 2017).

25. Zhengdao, L.; Fan, X.; Xiao, L.; Hong, J.; Geoffrey, Q.S. An Internet of Things-enabled BIM platform for on-site assembly services in prefabricated construction. Autom. Constr. 2018, 89, 146-161. [CrossRef]

26. Fadeyi, O. The role of building information modeling (BIM) in delivering the sustainable building value. Int. J. Sustain. Built Environ. 2017, 6. [CrossRef]

27. Sungyol, S.; Jeongsam, Y.; Namhyuk, K. Development of a BIM-based structural framework optimization and simulation system for building construction. Comput. Ind. 2012, 63, 895-912. [CrossRef]

28. Joosung, L.; Jaejun, K. BIM-Based 4D Simulation to Improve Module Manufacturing Productivity for Sustainable Building Projects. Sustainability 2017, 9, 426. [CrossRef]

29. Gulsum, S.B.; Ragip, A. Structured Evaluation of Pre-Construction Cost Alternatives with BIM and Resource Integrated Simulation. Comput. Constr. 2017, 499-506. [CrossRef] 
30. Li, J.; Jarde, A. Integrating Building Information Modelling (BIM), Cost Estimating and Scheduling for Buildings Construction at the Conceptual Design Stage. Master's Thesis, University of Ottawa, Ottawa, ON, Canada, 2016.

31. Kim, J.P.; Kwon, O.J.; Shim, H.S.; Kim, R.B.; Kim, J.H.; Woo, S.H. Analysis of Clinical Feature and Management of Fish Bone Ingestion of Upper Gastrointestinal Tract. Clin. Exp. Otorhinolaryngol. 2015, 8, 261-267. [CrossRef] [PubMed]

32. Chun, L. Cost Analysis and Control of Prefabricated Concrete Building Construction. Master's Thesis, Liaocheng University, Liaocheng, China, 2016.

33. Gabriel, L. The incremental cost principle and the conservation of globally important habitats: A critical examination. Ecol. Econ. 2008, 65, 216-224. [CrossRef]

34. Hadas, G.; Isaac, A.M.; Moshe, S.; Elia, W. Cost-benefit analysis of green buildings: An Israeli office buildings case study. Energy Build. 2014, 76, 558-564. [CrossRef]

35. Gayatri, V.; Kumar, N.J. What does it cost to convert a non-rated building into a green building? Sustain. Cities Soc. 2017, 36, 107-115.

36. Dubravka, M.; Jamie, R.; Miloš, E.; Babin, M. NGBS-Certified Single-Family Green Homes: Costs and Benefits. Des. Constr. 2017, 22, 05017001.

37. Lu, Y.; Wu, Z.; Chang, R.-D.; Li, Y. Building Information Modeling (BIM) for Green Buildings: A Critical Review and Future Directions. Autom. Constr. 2017, 83, 134-148. [CrossRef]

38. Dubravka, M.; Jamie, R.; Miloš, E.; Babin, M. Economically feasible energy refurbishment of prefabricated building in Belgrade, Serbia. Energy Build. 2014, 98, 74-81. [CrossRef]

39. Lara, J.; Chi, D.P. The evolution of prefabricated residential building systems in Hong Kong: A review of the public and the private sector. Autom. Constr. 2009, 18, 239-248. [CrossRef]

40. Jeff, H.; Eric, C.G.; He, J.; Gorodetzky, D.; Brown, N. A robust, cross-validation classification method (RCM) for improved mapping accuracy and confidence metrics. Can. J. Remote Sens. 2012, 38, 69-90. [CrossRef]

41. James, P.S.; Brian, J.R.; Todd, R. Policy Implementation and Cognition: Reframing and Refocusing Implementation Research. Rev. Educ. Res. 2002, 72, 387-431. [CrossRef]

42. Zhang, X.; Kuchinke, L.; Woud, M.L.; Velten, J.; Margraf, J. Survey Method Matters: Online/Offline Questionnaires and Face-to-Face or Telephone Interviews Differ. Comput. Hum. Behav. 2017, 71. [CrossRef]

43. Henry, A.; Joseph, H.M.T.; Cheung, F.K.T. BIM in Off-site Manufacturing for Buildings. J. Build. Eng. 2017, 14. [CrossRef]

44. Research on Engineering Quantity Calculation Method Based on BIM Software. Available online: https://wenku.baidu.com/view/ab6b88b2185f312b3169a45177232f60ddcce78d.html (accessed on 10 May 2018).

45. Peter, S. BIM \& the 5D Project Cost Manager. Procedia Soc. Behav. Sci. 2014, 119, 475-484. [CrossRef]

46. Comparison of Cost Comparison between Prefabricated Buildings and Traditional Cast-in-Place Buildings. Available online: https:/ / wenku.baidu.com/view/536ce2a126fff705cc170abb.html (accessed on 4 January 2014).

47. Westerweel, B.; Basten, R.J.I.; van Houtum, G.-J. Traditional or Additive Manufacturing? Assessing component design options through lifecycle cost analysis. Eur. J. Oper. Res. 2018, 270. [CrossRef]

48. Malik, K.; Tayyab, M. Current State of Off-Site Manufacturing in Australian and Chinese Residential Construction. J. Constr. Eng. 2014, 2014. [CrossRef]

49. Catarina, A.; Manuela, A.; Luís, B.; José, A. Cost-benefit analysis method for building solutions. Appl. Energy 2016, 173, 124-133. [CrossRef]

(C) 2018 by the authors. Licensee MDPI, Basel, Switzerland. This article is an open access article distributed under the terms and conditions of the Creative Commons Attribution (CC BY) license (http://creativecommons.org/licenses/by/4.0/). 